\title{
Severe Pulmonary Haemorrhage: An Uncommon Presentation of Plasmodium knowlesi
}

\author{
Şiddetli Pulmoner Hemoraji: Plasmodium knowlesi'nin Nadir bir Sunumu
}

Yeap Boon Tat, Rajesh Kumar Muniandy

Department of Medicine, Faculty of Medicine and Health Sciences, Universiti Malaysia Sabah, Sabah, Malaysia

\section{ABSTRACT}

Knowlesi malaria is widely researched and the most common cause of malaria in Sabah, northern east of Malaysia. Unlike the falciparum species, it is uncommon for knowlesi malaria patients to develop life threatening conditions. We report a case of a fatal knowlesi malaria complicated by pulmonary haemorrhage at our institution.

Key Words : P.knowlesi, pulmonary haemorrhage

Received: 10.06 .2018
Accepted:12.05.2018

\section{ÖZET}

Knowlesi sıtması, Malezya'nın kuzey doğusundaki Sabah'da yaygın olarak araştırılmış ve sıtmanın en yaygın nedenidir. Falciparum türlerinden farklı olarak, Knowlesi sıtma hastalarının yaşamı tehdit eden koşullar geliştirmesi nadirdir. Kurumumuzda pulmoner hemoraji ile komplike bir ölümcül knowlesi sıtma vakası sunduk.

Anahtar Sözükler: P.knowlesi, pulmoner kanama

Geliş Tarihi: 06.10.2018

Kabul Tarihi:05.12.2018

\section{INTRODUCTION}

Five species of Plasmodium parasites had been known to cause human malaria: $P$. falciparum, $P$. vivax, $P$. malariae, $P$. ovale and $P$. knowlesi . Of late, there are intense interests in research on knowlesi malaria after its first human endemic malaria which was discovered in Kapit, Sarawak in 2004(1). It is difficult to distinguish $P$.knowlesi from $P$. malariae parasites from human erythrocytes. Thus the advent of nested multiplex Polymerase Chain Reaction (PCR) assays can help detect $P$.knowlesi with very high sensitivity and specificity(2). Pulmonary haemorrhage complicating a knowlesi malaria is a rare occurrence. We report a case of young healthy man who developed severe pulmonary haemorrhage in a complicated malaria infection, who eventually succumbed to it.

\section{CASE REPORT}

A 32 years old gentleman with no known medical illness presented with one week history of fever and rigor associated with dry cough for five days, lethargy, myalgia and arthralgia for two days. There was no hemoptysis, haematemesis nor bleeding tendencies. On examination, he was alert and orientated, haemodynamically stable and afebrile. He was not tachypneic nor distress. There were no hepatosplenomegaly. Blood smear for malaria parasite ( BSMP) reported as Plasmodium malariae '4+'and mild thrombocytopenia (76×109/L) present. However, the Polymerase Chain Reaction (PCR) came back as $P$.knowlesi. The other biochemical parameters were within normal range. Blood culture and urine culture and sensitivity were negative. Dengue and leptospirosis screening were negative too. He was started on tablets Riamet ( artemether and lumefantrine) due to his uncomplicated malaria infections.

Address for Correspondence / Yazışma Adresi: Boon Tat Yeap, MD Department of Medicine, Faculty of Medicine and Health Sciences, Universiti Malaysia Sabah, Kota Kinabalu, Sabah, Malaysia E-mail: yeapboontat@gmail.com

CTelif Hakkı 2019 Gazi Üniversitesi Tıp Fakültesi - Makale metnine http://medicaljournal.gazi.edu.tr/ web adresinden ulaşılabilir.

CCopyright 2019 by Gazi University Medical Faculty - Available on-line at web site http://medicaljournal.gazi.edu.tr/

doi:http://dx.doi.org/10.12996/gmj.2019.22 


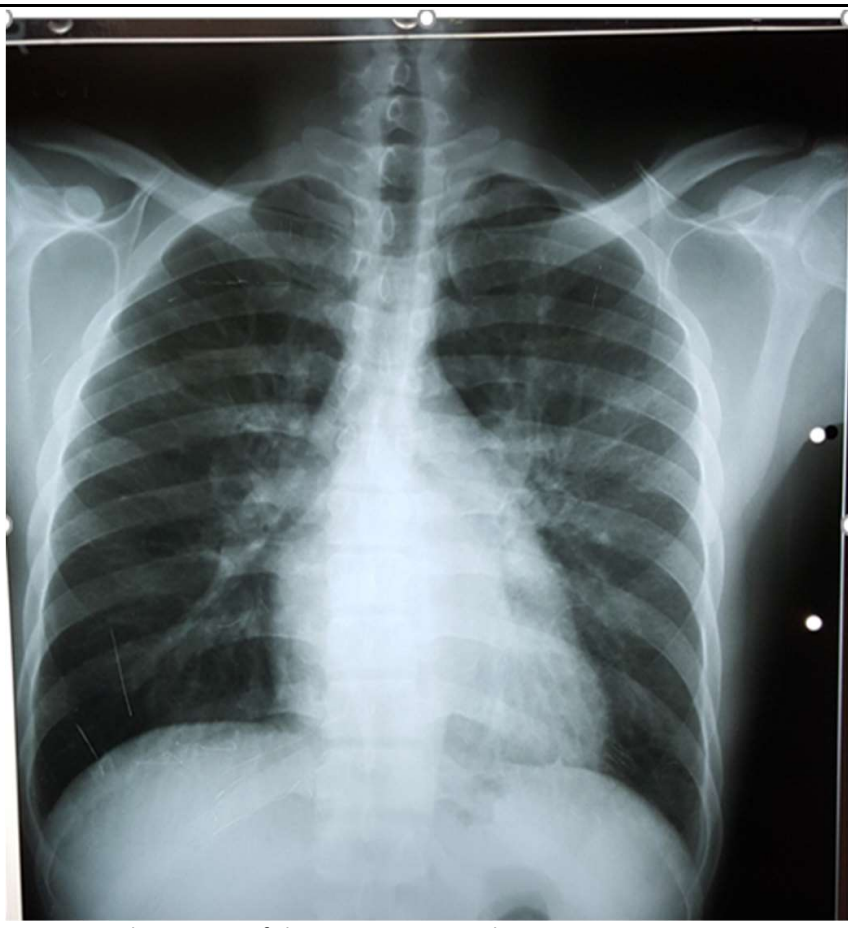

Figure 1 : Chest X-ray of the patient on initial presentation

However, the patient's conditions deteriorated a day after as he developed massive hemoptysis and was subsequently intubated and ventilated for severe pulmonary haemorrhage with type 2 respiratory failure. Intravenous artesunate was commenced. Chest radiograph showed diffuse bilateral pulmonary infiltrates, in keeping with Acute Respiratory Distress Syndrome (ARDS). The echocardiogram was normal findings. There were increasing needs of oxygen support with the $\mathrm{PaO} 2 / \mathrm{FiO} 2$ ratio persistently $<100$ and ventilation was difficult. The patient's condition worsened as he developed acute kidney injury ( AKI) with rising serum urea and creatinine and upper gastrointestinal bleed (UGIB) on day 4 of hospitalization. Urgent haemodialysis was commenced and blood components transfusion given with the support of ionotropes. There were mild thrombocytopenia with no derangement of the coagulation profile during his critical incident.

However, the patient succumbed to death at day six of admission due to severe pulmonary haemorrhage with underlying severe malaria. The family, however, refused for post mortem. The cause of death for this patient was classified as severe pulmonary haemorrhage secondary to knowlesi malaria.

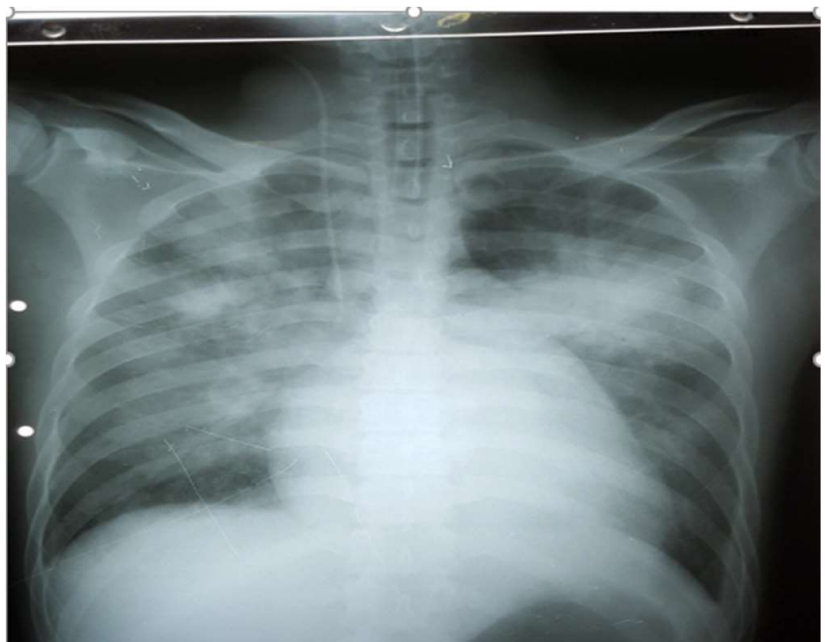

Figure 2 : Chest $X$ ray 2 days after admission showing bilateral infiltrates, consistent with ARDS.

\section{DISCUSSION}

Sabah is a state which is located at the eastern side of Malaysia, which encompasses a large range of ethnicity and religion. It is rich with green forests and have ample of resources.

Malaria is a blood borne zoonotics transmitted via the female Anopheles mosquitoes. It is a major public health issue in Malaysia, with Sabah recording the highest incidences at $74 \%$ followed by Sarawak at $15 \%$ (3). P.knowlesi accounted the highest cause of endemic malaria in Malaysia at 38\% and had raised more than ten -fold in Sabah between 2004 and $2011(3,4)$.

Patients who are infected with malaria usually complained of high fever with rigors, anorexia, joint and muscle ache and abdominal discomfort. It is not uncommon for patients with severe malaria to present with respiratory complications such as ARDS. Approximately 5 - $25 \%$ of adults with falciparum malaria developed ARDS upon initial presentation (5). This is due to the fact that falciparum parasite sequestrate into the pulmonary microvascular system during the asexual life cycle, thus causing increased capillary permeability and noncardiogenic pulmonary edema. However, ARDS is rare in vivax $(1-10 \%)$ and knowlesi malaria (6). The symptoms of respiratory failure often presents early in falciparum and knowlesi malaria patients while other species occur later. Patients who developed ARDS often have poor prognosis. Approximately $40 \%$ of patients will succumb despite adequate treatment and resuscitation; the mortality rates are higher with falciparum malaria (7). Cox-Singh J et.al in 2008 reported 4 fatal cases of severe knowlesi malaria in Sarawak which were complicated with ARDS; however the cause was not mentioned (8).

In our patient, he developed severe pulmonary hemorrhage which complicates ARDS on second day of hospitalization. This presentation is an uncommon presentation of knowlesi malaria. The pathophysiology of pulmonary haemorrhage in severe malaria remains unascertained. Disseminated intravascular coagulopathy (DIVC) was ruled out as the cause of pulmonary hemorrhage in our patient as the platelet levels, prothrombin time (PT) and activated partial thromboplastin time (APTT) were normal. As the patient developed worsening $\mathrm{AKI}$ and increasing urea levels, platelet dysfunction may contribute to the cause too. There is a possibility of post inflammatory state of alveolar capillary membrane (9). Despite the aggressive resuscitation efforts and early administration of intravenous artesunate, the patient succumbed to the illness.

\section{CONCLUSION}

Severe pulmonary haemorrhage as a cause of ARDS in knowlesi malaria is uncommon. The pathophysiology behind this condition remains uncertain. The prognosis is poor in patients who developed ARDS as a pulmonary complication of severe malaria. Prompt identification and management of severe malaria is crucial to reduce mortality rates.

\section{Conflict of interest}

No conflict of interest was declared by the authors.

\section{REFERENCES}

1.Singh B, Sung LK, Matusop A, Radhakrishnan A, Shamsul SS, Cox-Singh J, et al. A large focus of naturally acquired Plasmodium knowlesi infections in human beings. The Lancet. 2004;363:1017-24

2.Miguel-Oteo M, Jiram Al, Ta-Tang TH, Lanza M, Hisam S, Rubio JM. Nested multiplex PCR for identification and detection of human Plasmodium species including Plasmodium knowlesi. Asian Pacific journal of tropical medicine. 2017;10:299-304.

3.William T, Rahman HA, Jelip J, Ibrahim MY, Menon J, Grigg MJ, et al. Increasing incidence of Plasmodium knowlesi malaria following control of P. falciparum and P. vivax Malaria in Sabah, Malaysia. PLoS neglected tropical diseases. 2013;7:e2026.

4.William T, Menon J. A review of malaria research in malaysia. The Medical journal of Malaysia. 2014;69 Suppl A:82-7.

5.Taylor WRJ, Hanson J, Turner GDH, White NJ, Dondorp AM. Respiratory manifestations of malaria. Chest. 2012:142:492-505.

6.Mazhar F, Haider N. Respiratory Manifestation of Malaria: An Update. Internationa Journal of Medical Research \& Health Sciences. 2016;5:59-65.

7.Bruneel F, Hocqueloux L, Alberti C, Wolff M, Chevret S, Bedos JP, et al. The clinical spectrum of severe imported falciparum malaria in the intensive care unit: report of 188 cases in adults. American journal of respiratory and critical care medicine. 2003;167:684-9. 8.Cox-Singh J, Davis TM, Lee K-S, Shamsul SS, Matusop A, Ratnam S, et al. Plasmodium knowlesi malaria in humans is widely distributed and potentially life threatening. Clinical infectious diseases. 2008;46:165-71.

9.Anstey NM, Handojo T, Pain MC, Kenangalem E, Tjitra E, Price RN, et al. Lung injury in vivax malaria: pathophysiological evidence for pulmonary vascular sequestration and posttreatment alveolar-capillary inflammation. The Journal of infectious diseases. 2007;195:589-96. 